\title{
ESTIMATION OF INTERLEUKIN-6 FOR THE DIAGNOSIS OF SEPTICEMIA IN CHILDREN
}

\author{
Sanjoy Kanti Biswas 1 Md Anwar Husain ${ }^{2}$ Nasima Akter ${ }^{3}$ Md Tipu Sultan ${ }^{3}$ Nahid Sultana ${ }^{4}$ Md Shakeel Ahmed ${ }^{5}$
}

\begin{abstract}
Summary
Septicemia is a common cause of morbidity and mortality among children in developing world. Clinicians are in need of better diagnostic markers to diagnose septicemia. This study was carried out to evaluate the usefulness of interleukin-6 (IL-6) as a marker for the diagnosis of septicemia in children. Blood samples from 202 clinically suspected cases of septicemia and 20 age and sex matched healthy children were studied. On the basis of clinical features, blood culture and $C$ reactive protein (CRP) analysis results, study populations were categorized as culture proven septicemia $35(15.77 \%)$, probable septicemia 125 $(56.31 \%)$, non-septicemic febrile patient $42(18.92 \%)$. and healthy control $20(9.0 \%)$. Out of 35 culture positive cases, IL-6 estimation was done in 32 samples. In culture proven septicemia group, $28(87.5 \%)$ had IL-6 levels above cut-off value $>137 \mathrm{pg} / \mathrm{ml})$. In 20 probable septicemia and 10 non-septicemic febrile group, IL-6 level above cutoff value were found in $06(30 \%)$ and $01(10 \%)$ cases respectively. None of the healthy control group showed the concentration of IL-6 above cutoff value. The sensitivity and specificity of IL-6 were $65.38 \%$ and $95 \%$ respectively. Measurement of IL-6 may be a good marker to diagnose septicemia in children but this needs further evaluation on larger population.
\end{abstract}

Key words

Interleukin-6; septicemia; CRP

\section{Introduction}

Septicemia is the systemic illness caused by spread of microorganisms or their toxins via the blood stream ${ }^{1}$. The incidence rate of septicemia among industrialized nations was 50 to 100 cases per 100,000 individuals and in most developing countries it was 1 in 10 intensive care unit (ICU) patients ${ }^{2}$.

\footnotetext{
1. Assistant Professor of Microbiology Chattagram Maa-O-Shishu Hospital Medical College, Chittagong

2. Professor of Microbiology Chittagong Medical College, Chittagong

3. Associate Professor of Microbiology Chittagong Medical College, Chittagong

4. Associate Professor of Microbiology Chattagram Maa-O-Shishu Hospital Medical College, Chittagong

5. Lecturer of Microbiology Chittagong Medical College, Chittagong

Correspondence: Dr Sanjoy Kanti Biswas
}

The reported incidence of neonatal sepsis varies from 7.1 to 38 per 1000 live births in Asia, from 6.5 to 35 per 1000 live births in Africa and from 3.5 to 8.9 per 1000 live births in South America and the Caribbean ${ }^{3}$. A study in Khulna medical college hospital on neonatal infection had shown that septicemia $(34.6 \%)$ was the commonest major infection ${ }^{4}$. Despite all the advances in medical practices in recent years, septicemia continues to be a serious problem that needs immediate attention and treatment ${ }^{5}$. Blood culture, the gold standard for the diagnosis of septicemia requires up to 48 to 72 hours before the results are known and almost half of the positive samples do not show growth ${ }^{6}$. IL- 6 is an important cytokine of the early host response to infection. Its concentration increases sharply after exposure to bacterial products and precedes the increase in CRP. Blood IL-6 has been consistently shown to be a sensitive marker for diagnosing septicemia within 72 hours of infection, the sensitivities and negative predictive values being 87 $100 \%$ and $93-100 \%$ respectively ${ }^{7}$. So, this study has been designed to evaluate cytokine (IL-6) as biomarker for the diagnosis of septicemia in children.

\section{Materials and methods}

It was a cross sectional study, carried out in the department of Microbiology, Chittagong Medical college, during the period June 2006 to May 2007. Approval from Ethical review committee of Chittagong Medical College was duly taken. 202 clinically suspected cases of septicemia in the age group 0 day to 15 years and 20 age and sex matched healthy control were included in the study. The patients were selected randomly from the department of paediatrics of Chittagong Medical College and healthy controls were selected from the healthy children attending the patients in hospital with their parents.

\section{Inclusion criteria}

Patients were selected according to the following clinical features and laboratory findings ${ }^{8}$

Temperature : $>38^{\circ} \mathrm{C}$ or $<36^{\circ} \mathrm{C}$

Tachypnoea :

Respiratory rate $>40 / \mathrm{min}$. in children.

Tachycardia :

Heart rate $>$ normal limit for the age of child.

Leukocyte count $\quad:$ Leukocytosis $>15,000 / \mathrm{cmm}$. or Leukopenia $<5,000 / \mathrm{cmm}$. and $/$ or Band form $>10 \%$ 
At least two of the above four conditions with one or more of the followings, with or without localized site of infection were considered as suspected septicemia case.

- Fever with chills and rigor.

- Convulsion.

- Vomiting.

- Abdominal distension.

- Poor feeding.

- Lethargy/Listlessness.

- Skin septic spots.

- Jaundice.

- Hypotension.

- Hepato-splenomegaly.

- Obtundation of mental faculty - confusion, irritability or coma.

\section{Exclusion criteria}

- Neonatal asphyxia

- Haemorrhagic disease

- Congenital malformation

- Chromosomal anomalies

Study populations were grouped on clinical features, blood culture result and CRP concentration in blood ${ }^{9}$ as follows-

1. Culture proven septicemia group

2. Probable septicemia group

3. Non-septicemic febrile group

4. Healthy control group

\section{Laboratory procedure}

Blood cultures were performed by conventional method using Trypticase soy broth with 1-3 $\mathrm{ml}$ of blood from each patient. Subcultures were done in Blood agar, Chocolate agar and Mac-Conkey's agar plates after 24 hours, 48 hours and once before discarding the culture i. e. after 14 days. All plates were examined after 18-24 hours and discarded after 48 hours if no visible growth occurs. The organisms were identified by their colony morphology, staining characters, pigment production, motility and relevant biochemical tests as per standard methods ${ }^{10}$.

$2 \mathrm{ml}$ of blood from each patient were collected in a clean test tube and centrifuged at $10,000 \mathrm{~g}$ for 5 minutes. Serum were taken by using micropipette in two eppendorp tube, $50 \mu \mathrm{l}$ in tube no $\mathrm{I}$ and $500 \mu \mathrm{l}$ in tube no 2. Tube no 1, was used for CRP estimation and tube no 2 , was preserved at $-20^{\circ} \mathrm{C}$ for estimation of IL-6. Qualitative CRP estimation was done by latex agglutination method. Cytokine (IL-6) estimation was carried out by an automated method using chemiluminescence (Immulite DPC).

\section{Results}

On the basis of blood culture yield, CRP estimation results and clinical signs of septicemia, the study cases and controls were categorized into 4 groups. $35(15.77 \%)$ were blood culture proven septicemia (both blood culture and CRP positive), 125(56.31\%) were probable septicemia (blood culture negative, CRP positive), 42(18.92\%) were non-septicemic febrile patient (both culture and CRP negative) and $20(9 \%)$ were healthy control. Healthy control $(20)$ subjects were included in the study population for baseline cytokine (IL-6) study (Table-I).

Among 35 culture positive cases, S. typhi $17(48.57 \%)$ was the most commonly isolated bacteria followed by Klebsiella spp. $6(17.14 \%)$ Acinetobacter spp. 5(14.29\%), S. aureus 2(5.71) and Pseudomonas spp. 2(5.71), E. coli 01(2.86\%), Serratia spp. $01(2.86 \%)$ and N. meningitidis 01 (2.86\%) (Fig-I)

Table II shows the results of CRP among study cases. Out of 202 cases of clinically diagnosed septicemia in children $160(79.21 \%$ ) were CRP positive which includes culture positive cases and $42(20.79 \%)$ were negative

It appears from table-III that mean IL-6 levels $(\mathrm{pg} / \mathrm{ml})$ of blood culture proven septicemia, probable septicemia, non-septicemic febrile patient and healthy control group were 527.31, 233.58, 48.04 and 3.90 respectively. Significant differences were found when blood culture positive group were compared with blood culture negative groups $(\mathrm{p}<0.01)$.

Cut off value of IL-6 for septicemia was $137 \mathrm{pg} / \mathrm{ml}$. IL-6 values of 32 septicemia cases were in the range of $35.6-1000 \mathrm{pg} / \mathrm{ml}$ of which $28(87.5 \%)$ were above the cut off value and $04(12.5)$ were below. The concentration of IL- 6 in probable septicemia were in the range of $2-1000 \mathrm{pg} / \mathrm{ml}$, in non-septicemic febrile patients were $2-253 \mathrm{pg} / \mathrm{ml}$ and in healthy control group were $2-12.6 \mathrm{pg} / \mathrm{ml}$ (Table-IV).

The sensitivity of IL- 6 was $65.38 \%$, specificity $95 \%$ and positive and negative predictive values were $97.14 \%$ and $51.35 \%$ respectively (Table-V).

Table I : Categorization of cases and controls in different groups. $(n=222)$.

\begin{tabular}{lcc}
\hline Study groups & No. of patients & Percentage \\
\hline $\begin{array}{l}\text { Culture proven septicemia } \\
\text { (Both blood culture \& CRP positive) }\end{array}$ & 35 & 15.77 \\
$\begin{array}{l}\text { Probable septicemia } \\
\text { (Only CRP positive) }\end{array}$ & 125 & 56.31 \\
$\begin{array}{l}\text { Non-septicemic febrile } \\
\text { patient (Both blood } \\
\text { culture \& CRP negative) }\end{array}$ & 42 & \\
$\begin{array}{l}\text { Healthy control } \\
\text { Total }\end{array}$ & 20 & 18.92 \\
& 222 & 9.0 \\
\end{tabular}


Table II : Results of CRP in blood among study cases. $\mathrm{n}=202$

\begin{tabular}{lcc} 
CRP & No. of patients & Percentage \\
\hline Positive $(>6 \mathrm{mg} / 1)$ & 160 & 9.21 \\
Negative $(<6 \mathrm{mg} / 1)$ & 42 & 20.79 \\
Total & 202 & 100
\end{tabular}

Table III : Mean cytokine (IL-6) level in blood among different groups of study population.

\begin{tabular}{lll|}
\hline Study group & $\begin{array}{l}\text { Cytokine(lL-6) pg/ml } \\
\text { Mean } \pm \text { SD }\end{array}$ & Range \\
\hline $\begin{array}{l}\text { Culture proven } \\
\text { septicemia } n=32\end{array}$ & $527.31 \pm 359.30$ & $168.01-886.61$ \\
$\begin{array}{l}\text { Probable septicemia. } \\
\mathrm{n}=20\end{array}$ & $233.58 \pm 344.98$ & $111.40-578.56$ \\
$\begin{array}{l}\text { Non-septicemic febrile } \\
\text { patient. } \mathrm{n}=10\end{array}$ & $28.04 \pm 76.27$ & $28.23-124.31$ \\
$\begin{array}{l}\text { Healthy control } \\
\mathrm{n}=10\end{array}$ & $3.90 \pm 3.29$ & $0.61-7.19$ \\
\hline
\end{tabular}

Table IV : Result of cytokine (IL-6) estimation in blood among study population.

\begin{tabular}{|c|c|c|c|}
\hline \multirow[t]{2}{*}{ Study group } & \multicolumn{3}{|c|}{ No. of patients with IL-6 levels in $\mathrm{pg} / \mathrm{ml}$} \\
\hline & $>137$ & $<137$ & Range \\
\hline $\begin{array}{l}\text { Culture proven } \\
\text { septicemia } \\
\mathrm{n}=32\end{array}$ & $-28(87.5 \%)$ & $04(12.5 \%)$ & $35.6-1000$ \\
\hline $\begin{array}{l}\text { Probable } \\
\text { septicemia } n=20\end{array}$ & $06(30 \%)$ & $14(70 \%)$ & $2-1000$ \\
\hline $\begin{array}{l}\text { Non-septicemic } \\
\text { febrile patient } n=10\end{array}$ & $01(10 \%)$ & $09(90 \%)$ & $2-253$ \\
\hline $\begin{array}{l}\text { Healthy control } \\
n=10\end{array}$ & 0 & $10(100 \%)$ & $2-12.6$ \\
\hline
\end{tabular}

Values $>1000 \mathrm{pg} / \mathrm{ml}$ were considered as $1000 \mathrm{pg} / \mathrm{ml}$ and $<2 \mathrm{pg} / \mathrm{ml}$ were considered as $2 \mathrm{pg} / \mathrm{ml}$.

Table V : Sensitivity, Specificity and predictive values of cytokine (IL-6) results in study population

\begin{tabular}{lc|}
\hline & Cytokine (IL-6) \\
\hline Sensitivity & $65.38 \%$ \\
Specificity & $95 \%$ \\
Positive predictive value & $97.14 \%$ \\
Negative predictive value & $51.35 \%$
\end{tabular}

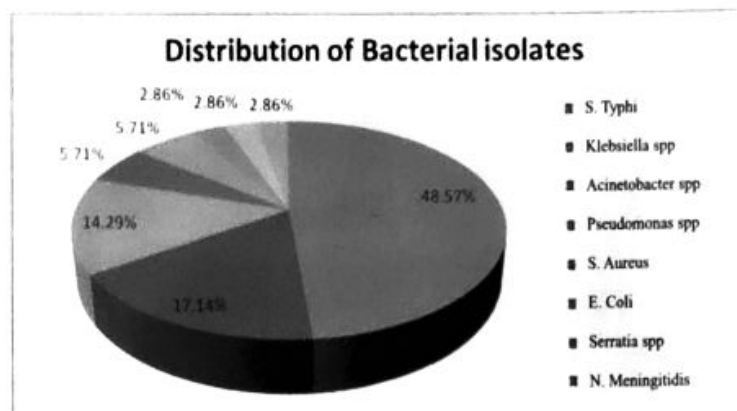

Fig 1: Distribution of bacteria isolated from blood culture

\section{Discussion}

In this study suspected septicemia cases were categorized on the basis of blood culture yield, CRP estimation results and clinical signs. Culture proven septicemia (both blood culture and CRP were positive) were $35(15.77 \%)$ cases, probable septicemia (only CRP positive) were $125(56.31 \%$ ) and non-septicemic febrile patient (both culture and CRP were negative) were $42(18.92 \%)$ cases. Healthy control 20(9\%) children were sampled for baseline cytokine levels. Similar categorization was done by Bhartiya et al. (2000) ${ }^{6}$ in India, Panero et al. $(1997)^{11}$ in Italy and Messer et al. (1996) ${ }^{12}$ in France. Messer et al. (1996) ${ }^{12}$ in France found $15.49 \%$ cases of proven septicemia, $49.29 \%$ probable septicemia and $35.21 \%$ cases was nonsepticemic febrile patient. This is consistent with the present study.

In our study, total 35 strains of bacteria were isolated and $\mathrm{S}$. typhi (48.57\%) was the most frequently isolated bacteria, followed by Klebsiella spp. (17.14\%), Acinetobacter spp. (14.29\%), Pseudomonas spp. (5.71\%), s.aureus (5.71\%), E.coli (2.86\%), Serratia spp. $(2.86 \%)$ and N. meningitidis $(2.86 \%)$. Our results are similar with those of Phetsouvanh et al. (2006) ${ }^{13}$ in Laos who found $50.9 \%$ S.typhi isolates from blood culture. Brooks et al. $(2005)^{14}$ in Bangladesh also found S.typhi as the common pathogen (75.4\%). Septicemia due to Salmonella was predominant in children of Bangladesh because of living in unhygienic conditions, lack of sanitation facilities and taking of unhygienic foods and unsafe water. In contrast to our findings, Ahmed et al. (2002) ${ }^{15}$ in Bangladesh, from Dhaka Shisu hospital revealed that the principal organisms were E.coli $(30 \%)$ followed by Klebsiella spp (23.3\%). 
Weinstein et al. $(1997)^{16}$ from U.S.A. reported that the most common blood stream isolate was S.aureus $(50.6 \%)$. These different findings in USA may be due to geographical difference, increased use of invasive procedures, extensive surgery, intravascular devices and increase in the number of immunocompromized persons (Kurruvillas 1988) ${ }^{17}$. In the present study out of 202 suspected cases of septicemia in children, $160(78.21 \%)$ patients were CRP positive $(>6 \mathrm{mg} / \mathrm{l})$ and $42(20.79 \%)$ patients were CRP negative $(<6 \mathrm{mg} / \mathrm{l})$. Similarly Makhija et al. $(2005)^{18}$ in India found CRP positive in $84.3 \%$ cases of suspected septicemia.

Mean level of IL-6 in culture proven septicemia, probable septicemia, non-septicemic febrile patient and healthy control group were $527 \mathrm{pg} / \mathrm{ml}, 233$ $\mathrm{pg} / \mathrm{ml}, 48 \mathrm{pg} / \mathrm{ml}$ and $3.90 \mathrm{pg} / \mathrm{ml}$ respectively. Significant differences were found when blood culture proven septicemia group were compared with blood culture negative groups $(\mathrm{p}<0.001)$. Similarly Makhija et al. (2005) ${ }^{18}$ in India found that mean IL-6 level was $480 \mathrm{pg} / \mathrm{ml}$ in proven septicemia, $264 \mathrm{pg} / \mathrm{ml}$ in clinical septicemia, 160 $\mathrm{pg} / \mathrm{ml}$ in non-septicemic control group and $2 \mathrm{pg} / \mathrm{ml}$ in healthy control group. Similar findings were also observed by panero et al. $(1997)^{11}$ in Italy and Messer et al. (1996) ${ }^{12}$ in France.

In our study the cut off value of Il-6 was $137 \mathrm{pg} / \mathrm{ml}$ for septicemia. Similarly Kallman et al. (1999) ${ }^{19}$ in Sweden used a cut-off value of $135 \mathrm{pg} / \mathrm{ml}$. Messer et al. $(1996)^{12}$ in France found a cut-off value of $100 \mathrm{pg} / \mathrm{ml}$. Some authors have proposed $50-500$ $\mathrm{pg} / \mathrm{ml}$ as a cut-off value (Bont et al. 1994) ${ }^{9}$. Variations in cut-off values are mainly due to different methods of measuring IL-6. In this study IL-6 values of 32 proven septicemia were in the range of $35.6->1000 \mathrm{pg} / \mathrm{ml}$. Out of 32 proven septicemia $28(87.5 \%)$ showed IL-6 levels above and $4(12.5 \%)$ cases below cut-off value for septicemia. IL-6 values of 20 probable septicemia cases were in the range of $2-1000 \mathrm{pg} / \mathrm{ml}$. Only 6 $(30 \%)$ cases had IL-6 levels above cut-off value and $14(70 \%)$ cases showed concentration of IL-6 below cut-off value. These large false negative results might be due to sampling later in the course of infection, delay in transportation, processing and preservation of samples for cytokine study. Only one patient in non-septicemic febrile group had IL-6 value above cut-off level. None of healthy control group showed the concentration of IL-6 above the cut-off value. Similar findings were also observed by Bhartiya et al. $(2000)^{6}$ in India who found $81.25 \%$ of proven septicemia had IL- 6 levels above the cut-off value and $18.75 \%$ had levels below the cut-off point.
In the present study sensitivity, specificity, positive predictive value and negative predictive value of IL6 were $65.38 \%, 95 \%, 97.14 \%$ and $51.70 \%$ respectively. Similarly Gaini et al. $(2006)^{20}$ in Denmark found sensitivity $70.3 \%$, specificity $89.5 \%$, positive predictive value $96.3 \%$ and negative predictive value $43.6 \%$ in diagnosing sepsis. Huang et al. (2003) $)^{21}$ in Taiwan showed that as a diagnostic test in children with sepsis serum IL-6 yielded a sensitivity of $68 \%$, specificity of $88 \%$, a positive predictive value of $71 \%$ and a negative predictive value of $58 \%$ which is similar to our findings. Lacour et al. $(2001)^{22}$ in Switzerland found sensitivity $79 \%$ and specificity $66 \%$ and Messer et al. $(1996)^{12}$ in France showed that presence of detectable level of IL-6 in blood was $83.3 \%$ sensitive and $90.3 \%$ specific for septicemia. In the present study slightly lower sensitivity rate than others could be due to smaller size of study population.

\section{Conclusion and recommendation}

Measurement of IL-6 may be a good marker in diagnosing septicemia. It needs a long term broad based study. All the conventional tests done to diagnose septicemia have limitations. So newer methods of diagnosis should be explored.

\section{Disclosure}

All the authors declared no competing interestes

\section{References}

1. Munford RS. Sepsis and septic shock. In: Fauci AS et al., eds. Harrison's principles of internal medicine. $14^{\text {th }}$ edition. The McGraw -Hill companies Inc. New York. 1998; 776-780

2. Zwirble WTL, Angus DC. Severe sepsis epidemiology: sampling, selection and society. Crit. Care. 2004; $4:$ 222-225

3. Vergnano $S$, Sharland $M$, Kazembe $P$, Mwansambo C, Heath PT. Neonatal sepsis: an international perspective. Arch. Dis. Child. Fetal Neonatal Ed. 2005; 90: F220-F224

4. Rasul $\mathrm{CH}$, Hassan MA, Habibullah M. Neonatal sepsis and use of antibiotic in a tertiary care hospital. Pak. J. Med. Sci. 2007; 23: 78-81

5. Nimri LF, Batchoun R. Community-acquired bacteremia in a rural area: Predominant bacterial species and antibiotic resistance. J. Med. Microbiol. 2004; 53: 1045-1049

6. Bhartiya D, Kapadia C, Sangvi K, Singh H, Kelkar R, Merchant R. Preliminary studies on IL -6 levels in healthy and septic Indian neonates. Indian Pediatr. 2000; 37: 1361-1367 
7. $\mathrm{Ng} \mathrm{PC}$. Diagnostic markers of infection in neonates. Arch. Dis. Child. Fetal Neonatal Ed. 2004; 89: 229-235

8. Kliegman RM and Behrman RF. Bacterial infections. Bacteremia and septicemia. In: Behrman RE, Kliegman RM, Nelson WE, Vaughan VC III, eds. Nelson Text book of pediatrics. $14^{\text {th }}$ ed. W.B. Saunders Company. Philadelphia. 1992; 681-682

9. Bont ED, Martens A, RannJV, Samson G, Fetter W, Okken A, Leij LD, Kimpen J. Diagnostic value of plasma levels of tumour necrosis factor (TNF ) and interleukin-6 (IL-6) in newborns with sepsis. Acta. Paediatr. 1994; 83: 696-699

10. Collee JG, Marr W. Culture of bacteria. In. Collee JG, Fraser AG, Marmion BP, Simmons A. eds. Mackie and McCartney Practical Medical Microbiology. $14^{\text {th }}$ ed. Churchill Livingstone. New York. 1996: 121-124.

11. Panero A, Pacifico L, Rossi N, Mancuso G, Stegagno $\mathrm{M}$, Chiesa $\mathrm{C}$. Interleukin-6 in neonates with early and lare onset infection. Pediatr. Infect. Dis. J. 1997; 16: 370-375

12. Messer J, Eyer D, Donato L, Gallatti H, Matis J, Simeoni U. Evaluation of interleukin-6 and soluble receptors of tumour necrosis factor for early diagnosis of neonatal infection. The J. pediatr. 1996; 129: $574-580$

13. Petsouvanh R, Phogmany $S$, Soukaloun D, Rasachak B, Soukhaseum V, Frichithavcong K. Causes of community-acquired bacteremia and patterns of antimicrobial resistance in Vientiane, Laos. Ann. J. Trop. Med. Hyg. 2006; 75: 978-985

14. Brooks AW, Hossain A, Goswami G, Sharmeen AT, Nahar K, Alam K, Ahmed N, Naheed A, Nair GB, Luby S, Breimen RF. Bacteremic typhoid fever in children in an urban slum, Bangladesh. Emerg. Infect. Dis. 2005; 11: 326-329
15. Ahmed NU, Chowdhury A, Houque M, Darmstadt GL. Clinical and bacteriological profile of neonatal septicemia in a tertiary level pediatric hospital in Bangladesh. Indian pediatr. 2002; 39: 1034-1039

16. Weinstein MP, Towns ML,Quartey SM, Mirrett $S$, Reimer LG, Parmigiani $G$ and Reller LB. The clinical significance of positive blood cultures in 1990s: A comprehensive evaluation of the microbiology, epidemiology and outcome of bacteremia and fungemia in adults. Clin. Infect. Dis. 1997; 24: 584-602

17. Kuruvilla AC. Neonatal septicemia. Indian J. Pediatr. 1988; 55: 225-233

18. Makhija P, Yadav S, Thakur A. Tumour necrosis factor and interleukin- 6 in infants with sepsis. Indian pediatrics. 2005 ; 42: 1024-1028

19. Kallman J, Ekholm L, Eriksson M, Malmstrom B, schollin J. Contribution of interleukin-6 in distinguishing between mild respiratory disease and neonatal sepsis in the newborn infant. Acta. Pediatr. 1999; 88: 880-884

20. Gaini S, Koljaer OG, Pedersen C, Pedersen SS. Procalcitonin, lipopolysaccharide-binding protein, interleukin-6 and C-reactive protein in communityacquired infections and sepsis: A prospective study. Crict. Care. 2006; 10:R53

21. Huang SY, Tang RB, Chen SJ,Chung RL. Serum interleukin-6 level as a diagnostic test in children with sepsis. J. Chin. Med. Assoc. 2003; 66: 523-527

22. Lacour AG, Zamora SA, Gervaix A. Vadas L, Lombard PR, Dayer JM, Suter S. Procalcitonin, IL6, IL-8, IL-1 receptor antagonist and C-reactive protein as identificators of serious bacterial infections in children with fever without localizing signs. Eur. J. pediatr. 2001; 160: 95-100 